\title{
Pork-Barrel Politics and Electoral Reform: Explaining the Curious Differences in the Experiences of Thailand and Japan
}

\section{RAY CHRISTENSEN AND JOEL SAWAT SELWAY}

A comparison of recent Thai and Japanese politics presents a puzzle. Both nations undertook similar electoral reforms at about the same time, but the results have been dramatically different. Thai leaders are party-oriented and have shifted away from the pork-barrel politics of the past. Japanese leaders and members of parliament remain candidate-oriented and continue Japan's pork-barrel policies. We explain these divergent outcomes by analyzing the different causes of and politics surrounding the electoral reform efforts in both countries. Our findings join with the growing literature that questions the one-way causal effects that are usually purported to flow from institutional changes. Rather, we argue that new institutions, such as new election systems, can be as much a result of political changes as a cause of those same changes.

\section{INTRODUCTION}

$\mathrm{I}$ THE 1990s, Two of Asia's largest democracies, Japan and Thailand, undertook significant constitutional and legislative reforms with the intent of creating more responsible, policy-focused political parties. The spark in Japan was a policy immobilism that led to economic decline, the thwarting of anti-corruption reform proposals, and an inability to respond well to international crises. In Thailand, it was the 1997 financial crisis, which shaved off approximately one-tenth of the gross domestic product (GDP) and would eventually engulf most of Asia. Politicians, rightly so, took the brunt of the blame. In both countries, politicians had routinely put narrow self-interests that helped their reelection prospects ahead of national interests. One manifestation of this democratic deficit was pork barrel politics, the inefficient use of government funds to favor local constituencies over broad, national policies and programs. A second manifestation was termed crony capitalism, which described the close relationship between businesses and politicians that was widespread in Japan and Thailand. Politicians in both countries routinely received kickbacks or promises of electoral support in exchange for providing loans or bailout funds to under-performing businesses. The reforms were supposed to correct the incentives Thai and Japanese politicians had to engage in such behavior.

Periods of major reform are infrequent occurrences in the democratic world, but ones that provide scholars the opportunity to assess the effect of one of the largest

Ray Christensen (ray_christensen@byu.edu) is Associate Professor of Political Science at Brigham Young University. Joel Sawat Selway (joel_selway@byu.edu) is Associate Professor of Political Science at Brigham Young University. 
subfields of comparative politics: institutions. Political scientists employ large crosscountry datasets of these changes in the hopes of providing evidence for generalized claims regarding how institutions shape anything from voter turnout or economic growth to civil wars or health outcomes. The Thai and Japanese reforms were remarkably similar, and would be placed in the same categories of the main characteristics along which scholars differentiate political institutions. Institutional theories, moreover, predict that these reforms would result in a reduction in pork barrel politics and crony capitalism.

A survey of the literature on both countries seems, at first blush, to support these predictions. However, a close comparison of Thailand and Japan quickly reveals important differences. In the seventeen years since electoral reform, Thai politicians have given priority to national-level policies and public goods provisions over the extreme levels of constituency service and pork-barrel politics that characterized their work under the previous electoral system. In contrast, despite the new electoral rules and a vigorous attack on pork-barrel spending by a prominent Japanese prime minister, porkbarrel spending continues to play an important role in Japanese politics. To what degree, then, can we ascribe causality for such divergence to the similar reforms described above?

This anomalous outcome is what we intend to explain. After compiling extensive data on the characteristics of members of parliament (MPs) under the new electoral systems, the characteristics of party leadership under the new systems, and types of government spending, we found that the difference in policy outcomes is also mirrored in significant differences in both party leaders and rank-and-file MPs. We identify idiosyncratic electoral rules and party practices that largely account for the dramatic difference in legislative, leadership, and spending outcomes between Thailand and Japan. In addition, we trace the root cause of these differences back to the electoral reform process itself. Rather than the new election rules shaping political outcomes, we found constitutional writers in Thailand and party leaders in Japan shaping the new electoral rules to produce the outcomes that they wanted.

This finding parallels a similar debate about the origins of electoral systems in both long-standing democracies and recently democratized countries (Colomer 2005; Kaminski 2002; Persson and Tabellini 2003). This debate identifies a variety of factors, including existing party systems, perceived political threats, ideology, and economic conditions, that explain why elites choose a specific set of election rules (Alesina and Glaeser 2004; Benoit 2007; Blais, Dobrzynska, and Indridason 2005; Boix 1999; Carstairs 1980; Cusack, Iversen, and Soskice 2010; Ticchi and Vindigni 2010). These differing motivations for reform can shape the ultimate effect of such constitutional changes as reformers manipulate other seemingly tangential formal rules, the implementation of these rules, and the informal understanding of the rules.

Untangling both the two-way causality and the multiple causes of electoral rule changes is difficult in the large- $\mathrm{N}$ quantitative studies that characterize most political science scholarship. Single case studies are able to marshal thick description and in-depth knowledge of history, political actors, and local conditioning factors that can help elucidate the mechanisms and sort amongst competing explanations. Nevertheless, additional insights about the effect of institutions within a particular country can be fruitfully gained from a comparative study with other countries, even just one, if well-selected for theoretical reasons. Such small-N research designs can preserve the richness of 
qualitative studies while contributing to more generalizable claims. The current study is best classified as a Most-Similar-Different-Outcomes qualitative design in which cases are selected to be most similar on the explanatory variables but to have different outcomes known a priori to the conducting of research (Ragin and Becker 1992).

The findings that emerge from this research design warn against institutional naiveté, the simple assumption that certain institutions can solve intractable political problems such as pork-barrel politics, corruption, or democratic instability. Rather than placing unwarranted faith in the ability of certain institutions to deliver specific policy outcomes, pro-reform forces should be aware of how the reform process, especially in mixed electoral systems, is open to manipulation by other seemingly less important rules or party practices. Thus, the most important requirement of a successful reform effort is creating buy-in among elites that a specific reform is needed, such that competing rules do not undermine a specific effort.

\section{The Limits of Institutional Explanations}

An extensive literature exists that explains politics through an understanding of the institutions that shape the incentives for politicians' behavior. One of the growth areas in this field is the study of election systems and the incentives that they create for politicians. Electoral rules have been cited as explanations for a wide variety of political behaviors, including budgetary discipline (Hallerberg and Marier 2004), trade protectionism (Nielson 2003), corruption (Chang and Golden 2007), party unity (Carey 2007), and public goods expenditures (Hicken and Simmons 2008).

We are interested in how election rules discourage or encourage particularistic (pork-barrel) policies rather than programmatic (nationally oriented) policies. The scholarly consensus is that electoral systems that encourage candidate-centered voting produce MPs who are more inclined to produce particularistic policies. In contrast, electoral systems that encourage party-centered voting tend to produce politicians who pursue nationally oriented policies (Crisp and Desposato 2004; Edwards and Thames 2007; Lancaster 1986; Lancaster and Patterson 1990; Thames and Edwards 2006).

Political scientists divide electoral rules into two main families: majoritarian and proportional representation (PR). Under majoritarian rules, individuals who may or may not be backed by a party compete against other individuals, most commonly in single-seat districts. The single candidate with the most votes wins. ${ }^{1}$ Majoritarian electoral rules connect politicians with local constituencies, the potential advantage of which is an understanding of and willingness to voice local concerns. The disadvantage is that candidates have strong incentives to emphasize their individual merits and achievements. Not surprisingly, scholars identify majoritarian electoral rules as producing candidate-centered voting. In contrast, PR is associated with party-centered voting. Under PR, voters select parties (not individuals) in geographically larger multi-seat districts. The district size helps politicians think about concerns of larger groups of citizens, while the selection of parties rather than individuals augments that with a focus on programs that tend to be

${ }^{1}$ This can either be a plurality (most votes, no threshold) or a strict majority (50 percent plus 1$)$ that is usually enforced through a two-round run-off. 
nationally focused. ${ }^{2}$ Party-centeredness is also affected by other features of the electoral system, including district magnitude (the number of seats up for grabs within a district), central party control over nominations and electoral funding, and ballot structures (Carey and Shugart 1995; Hallerberg and Marier 2004; Johnson and Wallack 2010; Nielson 2003).

Both Thailand and Japan had extreme forms of majoritarian electoral rules prior to the electoral reforms in the 1990s. First, both countries had a rare form of multi-seat majoritarianism. In these multi-seat districts, candidates of the same party would run in a large field of contestants along with multiple candidates from other parties. Candidates from the same party, however, would not act as a team. In fact, the incentives were such that emphasizing individual merits over party policies was the only way to differentiate oneself from other candidates of the same party. ${ }^{3}$ As a result, candidates from the same party ran against each other in the same electoral districts, and both nations were seen as extreme cases of candidate-centered politics with pork-barrel politics and particularistic benefits being the primary functions of their legislators (Curtis 1971; Hicken 2002; Ockey 1994; Scheiner 2006).

Both countries moved away from a majoritarian system as part of their electoral reforms. They did not, however, select a pure PR system. Instead, they opted for a third type of electoral system that has steadily grown in popularity since the 1990s. These are systems that combine elements of both majoritarian and PR electoral rules. They are known as mixed electoral systems. To be precise, a mixed electoral system is one in which there are two tiers of politicians within a single legislature, each tier elected by a different family of electoral rules. The idea is to obtain "the best of both worlds," to borrow the title of a widely read book on the subject (Shugart and Wattenberg 2001). Mixed systems get politicians elected by both rules, and thus has a legislature potentially filled with politicians concerned about both local and national concerns.

But are mixed systems simply in-between majoritarian and PR systems in terms of candidate- versus party-centeredness? Batto (2012) illustrates a much more complex picture. He reviews twenty-one studies that measure party-centeredness by looking at party cohesion in legislative votes, breaking down MPs into two groups-those elected on party lists and those elected in individual districts. He finds that in four countries the district MPs have low party discipline, in six countries the list MPs have low party discipline, and in eleven countries the results are inconclusive.

To tackle this problem, scholars have tried to isolate the most important variation in mixed electoral systems and predict policy outcomes based on different combinations of those rules. Mixed systems may allow for more variation in outcomes, but that variation can be explained by simply identifying the sources of that variation. First, mixed electoral

\footnotetext{
${ }^{2}$ In some versions of PR (e.g., open-list PR) voters can select a party and an individual candidate within that party, thereby pushing him or her up the party rankings. Scholars see this version of PR as more candidate-centered than the version in which voters can select only a party (closed-list PR).

${ }^{3}$ Japan used a single non-transferable vote (SNTV) system in which voters had one vote to cast among several competing candidates in the same district. Thailand used a bloc vote system in which voters had as many votes as there were seats to be filled in a district. In theory, the bloc vote should not encourage intra-party competition, but in Thailand, it operated similarly to the SNTV vote system used in Japan.
} 
systems allow variability in the size of tiers, and having a larger-sized PR tier should increase the number of MPs elected by party-centered voting and thus the partycenteredness of a mixed system (Shugart and Wattenberg 2001).

Second, mixed systems can be either linked or unlinked. In a linked system, the PR tier compensates for disproportionality in the majoritarian tier. In majoritarian districts, the winner takes all. It is technically possible for one party to win all the seats. But in a linked mixed system, the PR tier would give the other parties more seats until it evens out to match each party's performance in the PR tier rather than the majoritarian tier (Moser 2001; Shugart and Wattenberg 2001). Thus, greater effort or victories in district races are cancelled out in linked systems by a corresponding reduction in the number of party-list seats that the party wins. Parties in a linked system can improve their overall electoral performance only by increasing their shares of the party vote, because the number of seats that a party wins in its districts is largely irrelevant to the total number of seats the party holds in the legislature. In unlinked systems, effort in both tiers is rewarded with seats.

Third, mixed systems can allow candidates to dual list, running in both a district race and on a party list in the PR tier. Several authors have noted that dual listing allows candidates in majoritarian districts to be influenced by the incentives of the PR tier or that party-list candidates can be influenced by the incentives of district races (Barker et al. 2001; Crisp 2007; Ferrara 2004; Herron and Nishikawa 2001; Klingemann and Wessels 2001). The net effect of dual listing should be to enhance party-centeredness because candidates will prefer party-list races to district races.

Party-list campaigns require less effort and fundraising by individual candidates than comparable campaigns in a district. In addition, the proportional allocation nature of the PR tier means that there are more safe seats (won by the party in multiple, consecutive elections) on party lists than in district races. In contrast, there can only be one winner in a district seat, making a greater proportion of these seats less sure for a party in a bad election year. For example, 84 percent of the seats that the Liberal Democratic Party (LDP) won on its party lists in Japan's three elections from 2005 to 2012 were seats that the LDP won in all three elections. In contrast, in district races in those same three elections, the LDP won only 30 percent of those seats in all three elections. The Democrats have a similar record, consistently winning 51 percent of their party-list seats but consistently winning only 17 percent of their district seats. Of course, candidates who prefer to be independent of party leaders might prefer to run their own district race, even if it is more costly or less sure of victory. They might value independence more highly than the ease or likelihood of victory. All other factors being equal, though, candidates will prefer party-list positions over district positions.

So, how do these three major rules fare in explaining the differences between the Thai and Japanese cases? As it turns out, not so well. First, it should be noted that both mixed systems are fairly similar. Both countries have relatively large majoritarian tiers that should make their elections more candidate centered. They both also use unlinked systems, which should again reduce the influence of their party-list tiers, keeping their elections more candidate centered. Their only difference is the dual listing of candidates, which is allowed in Japan and not allowed in Thailand. This one difference, however, predicts the opposite outcome than what has actually occurred. The dual listing of Japanese MPs should increase the influence of party-list incentives on 
district MPs, enhancing the average party-centeredness of all Japanese MPs. In practice, however, Japan's MPs have continued their long history of particularistic policies and pork barrel politics. Similarly, Thai MPs are not dual listed, effectively insulating the majority of Thai MPs from the incentives and influences of party-list races. Nevertheless, these MPs have supported policy programs that have emphasized the provision of nationallevel goods rather than continuing the Thai tradition of pork-barrel politics and districtlevel spending. The subsequent section compares these two cases in detail to uncover the factors that are responsible for these patterns.

\section{Electoral Rules and Party Practices}

We look at two measures of how party-centered Japan and Thailand's mixed systems are. First, we examine effective tier size. Formally, Japan's PR tier is larger, ranging from 37.5 percent to 40 percent, compared to Thailand's 16 percent to 25 percent range. This would seem to predict the opposite of what we actually observe in terms of policy outcomes. However, Japan's PR tier has effectively been 12 percent to 27 percent, much closer to Thailand's. This discrepancy is explained by an idiosyncratic electoral rule in Japan known as the "best loser" system as well as Japanese parties' practices in response to this and the dual-listing provision. Collectively, these result in many of the nominally PR-tier MPs actually being district-reliant. In contrast, because there is no dual listing in Thailand, the number of party-list MPs is exactly what the electoral law specifies.

Thailand also has its own idiosyncratic electoral rules that further pushed Thailand in the direction of party-centeredness. This is manifested in the proportion of cabinet members in each country that comes from the PR tier. In Thailand this has ranged from 56 percent to 100 percent, while in Japan it has floundered at 0 percent to 11 percent. In sum, we find that in Japan, for both MPs and party leaders, party-list MPs are rare or sidelined to such an extent that Japan's national legislature is best characterized as a bastion of candidate-centered politics, while the opposite is true in Thailand.

We discuss two factors that account for the diverging outcomes under the "same" electoral rules, at least as far as the most common classifications are concerned. First, we consider idiosyncratic electoral rules that can undermine the major rules of tier size, linkage, and dual listing. Second, we look at party practices: both those in response to formal rules and those particular to each country.

\section{Idiosyncratic Rules}

Both countries included idiosyncratic electoral rules in their electoral reforms that pushed in opposite directions in terms of how candidate- versus party-centered the resultant system became. Japan's dual-listing rule by itself should have pushed in the direction of party-centeredness. However, the option of a "best loser" provision in selecting winners from party lists transformed those PR-tier seats into district-reliant ones. The best loser provision allows parties to put candidates on their party lists at the same position, using how close each candidate came to winning his or her district race as the tiebreaking mechanism. District winners are automatically removed from consideration for party-list seats, but of the remaining losers, their rank on the party list is moved up or down by how close each loser came to actually winning his or her district race. Thus, 
the best loser provision makes it possible for parties to convert party-list seats into the equivalent of district seats (McKean and Scheiner 2000; Reed 1995). The result is that many of those elected on Japan's party lists win their seats not because of their position on the party list but because of how close they came to winning their simultaneous district race. Indeed, when Japanese politicians are categorized by whether they won their seat because of their position on a party list (list-reliant victors) or by their performance in a district race (district-reliant victors), the candidate-centeredness of the Japanese legislature increases. The legislature itself is 37 to 40 percent party-list MPs, but the number of list-reliant MPs drops to 30 percent in the first post-reform elections. In the five elections from 2003 to 2014, the number of list-reliant MPs drops further to only 15 percent of the legislature on average. ${ }^{4}$

A second formal electoral rule, in response to concerns that some dual-listed candidates were winning seats on party lists despite having won only a small share of their district vote, was passed in the Japanese legislature in 2000. The rule requires that dual-listed candidates win at least 10 percent of the district vote to be eligible to win a seat on a party list. The Socialists dual list nearly all their candidates, placing them at the same position on party lists, but many of these candidates fail to meet the 10 percent threshold, disqualifying them from the party list. The party, therefore, puts "placeholder" candidates at the bottom of its party lists, candidates that are not dual listed and therefore are exempt from the threshold vote requirement. If all of the Socialists' dual-listed candidates in a region fail to meet the required threshold, the placeholder candidate takes the seat that the Socialist Party won.

Thailand also has its own idiosyncratic rules, not captured in any of the main characteristics of mixed systems, that strongly influence the large parties to put their most prominent people on the party list. Article 118 of the Thai Constitution states that all MPs have to give up their seat in parliament in order to serve as a minister; for the partylist MPs, the minister would be replaced by the next person down on the list. However, naming a district MP to the cabinet would require a by-election to fill the district seat. From a party perspective, it makes sense to list all potential cabinet members on the party list because they can be replaced without risking a loss of legislative seats in by-elections.

Table 1 presents data on the 2001, 2005, 2007, 2008, and 2011 governments. ${ }^{5}$ Nominally, a different party led four of these five governments, though the Thai Rak Thai (TRT), People's Power (PPP), and Pheu Thai parties are essentially the same party. Being subject to a string of dissolutions by the Constitutional Court, party leaders simply registered a new party, keeping the core of the leadership mostly intact. We should note here that Thailand's democracy has been interrupted by two coups since

\footnotetext{
${ }^{4}$ The number of list-reliant MPs were 29 percent in the 1996 election; 27 percent in 2000; 16 percent in 2003; 17 percent in 2005; 18 percent in 2009; 13 percent in 2012, and 12 percent in 2014. In a few cases, the classification of candidates can be difficult. For example, if a candidate was given a preferential position on the party list but also won his or her district seat, we classified that candidate as district-reliant even though he or she could have also benefited from favorable placement on the party list.

${ }^{5}$ There was no cabinet installed after the 2006 elections, which the major opposition party, the Democrats, boycotted.
} 
Table 1. The ratio of district- and list-reliant MPs in Thailand's cabinet.

\begin{tabular}{|c|c|c|c|c|c|c|}
\hline & Districts & $\begin{array}{c}\text { PR } \\
\text { Lists }\end{array}$ & Non-MPs & $\begin{array}{c}\text { Total } \\
\text { Cabinet } \\
\text { Positions }\end{array}$ & $\begin{array}{l}\text { District/ } \\
\text { PR Ratio }\end{array}$ & $\begin{array}{c}\text { District/Total } \\
\text { Positions } \\
\text { Ratio }\end{array}$ \\
\hline $\begin{array}{l}\text { Thai Rak Thai, } \\
\text { Feb. } 2001 \text { - } \\
\text { Mar. } 2005\end{array}$ & 1 & 26 & 11 & 38 & 0.04 & 0.03 \\
\hline $\begin{array}{l}\text { Thai Rak Thai, } \\
\text { Mar. } 2005- \\
\text { Sept. } 2006\end{array}$ & 0 & 9 & 27 & 36 & 0.00 & 0.00 \\
\hline $\begin{array}{l}\text { People's Power, } \\
\text { Feb. } 2008- \\
\text { Dec. } 2008\end{array}$ & 4 & 11 & 22 & 37 & 0.36 & 0.11 \\
\hline $\begin{array}{l}\text { Democrat, } \\
\text { Dec. } 2008 \text { - } \\
\text { Aug. } 2011\end{array}$ & 16 & 5 & 15 & 36 & 3.20 & 0.44 \\
\hline $\begin{array}{l}\text { Pheu Thai, } \\
\text { Aug. } 2011 \text { - } \\
\text { May } 2014\end{array}$ & 15 & 12 & 12 & 39 & 1.25 & 0.38 \\
\hline
\end{tabular}

the 1997 Constitution was written. From one point of view, that of democratic consolidation, then, the Constitution seems to have not been successful. However, we are looking solely at the effect on public goods provision, and we provide evidence that policy style in this regard has endured even throughout the two coups, at least whenever elected politicians held the reins of government. Despite the complexity of the political situation during this period of time, our argument only requires that the government budgeting environment was independent of other political actors (such as the military). One indicator of this independence is how free and fair the elections were, which international election observers seem to agree on (ANFREL 2008, 2011). Our following of the Thai news during this period of time also did not indicate pressure from external actors influencing government budgeting decisions.

We begin with TRT, the first party to take office after the new electoral rules came into play in 2001. We see strong evidence that the party list was the most valued by the TRT leadership. Only one cabinet member, Sontaya Khunpluem (Roi Et), was elected in a district. She took up one of the less important posts, Minister of Science, Technology, and the Environment. Of the remaining thirty-seven positions, twenty-six came from the PR tier and eleven were non-MPs appointed by the prime minister. We could easily consider these eleven non-MPs as equivalent to party-list MPs because they also are wholly reliant on the party leadership for their posts. Indeed, in TRT's subsequent government, Prime Minister Thaksin Sinawatra selected twenty-seven non-MPs. Many of them had run on the party list in the previous elections; others were party executives, with the remaining being TRT affiliates in the Senate (who legally were not allowed to run under a party banner) and other important supporters of the party.

Two other idiosyncratic formal rules in Thailand contributed to this tendency for parties to list party leaders on the PR tier. First, the 5 percent threshold rule on the 
PR tier stated that only parties that gained 5 percent of the vote or more could receive any seats. This meant that the larger parties would be awarded extra seats, making them able to safely list more party leaders on their ballot. ${ }^{6}$ Second, the Thai Constitution included a rule to prevent MPs from switching parties between elections. This had been a common practice in Thailand because party labels were essentially meaningless. The partyswitching rule barred MPs from rerunning if they had switched within ninety days of the election. This gave the prime minister the power to call elections if a mass defection occurred. The rule strengthened parties, especially the ruling party. Factions dissatisfied with the party leadership would have to remain loyal to party leadership and their policy direction. $^{7}$

\section{Party Practices}

As Moser (2001) notes in his analysis of unexpected outcomes in Russia’s first democratic elections, the context-especially the party context-matters in figuring out the effects of a specific electoral rule. Party practices in each country responded to the political climate, electoral competition, and further formal rules to further shape the partycenteredness of each country. First, we consider the political climate. The first elections following the 2006 coup saw TRT dissolve, and its supporters split into several parties. The largest successor party, PPP, took office in the 2008 elections. To form a government, however, PPP had to join forces with other small parties (five in total, though not all were vital). Although the combined parties highly resembled the former TRT party, because the smaller parties competed separately and faced different pressures from electoral competition (discussed below), this forced PPP to make different choices regarding the composition of its cabinet than the TRT cabinets. But this was not confined to the effect of smaller parties. The uncertainty of the political climate even affected the largest party, PPP, which listed two of its eventual cabinet members on the majoritarian tier.

The pressures from electoral competition in Thailand led to different party practices for small and large parties in all elections. While they only affected cabinet outcomes in turbulent political climates, party size was a potential shaper of any cabinet. Specifically, small parties saw the PR list as highly uncertain. Unsure of winning any list seats, they simply lacked the option that the larger parties had of listing the party leaders (potential cabinet members) on the PR list. Instead, they had to put their prominent politicians in district seats that the politician was likely to win. In total, still only four of the thirty-seven cabinet positions came from the district tier in the 2008 PPP cabinet. Two of these four were from the small parties. Two were PPP members. It should be noted that three of these four positions were deputy ministerial positions, with the last being the low-ranked Minister of Science and Technology. Thus, we still observe a very low proportion of district MPs taking cabinet seats.

${ }^{6}$ Japan's official nationwide threshold is 2 percent, but because the largest PR district is thirty seats it is effectively around 3 percent. Regardless, this indicates a higher tolerance for smaller parties within the Japanese system.

${ }^{7} \mathrm{~A}$ ban on party switching has been extensively discussed in Japan, and a weak version was implemented in 2000 . 
Political climate and party size also affected the composition of the Democrat Party cabinet in December 2008. After the Constitutional Court dissolved PPP, the Democrats had to form a government with just 165 of 480 seats in the legislature. In addition to being a smaller party than PPP, they had to rely much more on the smallest parties and even required some defections from PPP. The Democrat Party itself never expected to form a government and relied less on PR-tier MPs than PPP or TRT. It is no surprise that we see the highest ratio of district to list seats in this period, then. Sixteen of the thirty-six seats came from district MPs: eight Democrat, three Chart Thai, two Pheu Paen Din, and one Neutral Democrat. Only five came from the party lists, and they were all Democrat candidates. However, there were an additional fifteen non-MPs who owed their positions directly to the leadership of the Democrat Party. This was Thailand's highest district/PR ratio of 3.2, which was still much lower than Japan's average of 19.3 .

Further examination suggests that these outcomes may also have been a result of the political climate in which the Democrat Party found itself-assuming government in the wake of the largest party being dissolved. We thus looked at the two times the Democrat Party set up a shadow cabinet (the only party to do so to date in Thailand). ${ }^{8}$ Table 2 shows these two shadow cabinets. The first shadow cabinet was in February 2008, following PPP's selection of Somsak Wongsawat as prime minister. ${ }^{9}$ This first shadow cabinet had a lower proportion of district-reliant MPs than the actual Democrat-led government, most similar to Pheu Thai's (the most recent incarnation of TRT) 2011 cabinet, although still higher than the TRT and PPP governments. The Democrats' most recent shadow cabinet is much closer to TRT and PPP. Only two positions in the shadow cabinet are given to district MPs, compared to eighteen from the party lists and seventeen non-MPs. In sum, the uncertain political situation in Thailand made it much less partycentered than it would have otherwise been.

Party practices in Japan further exacerbated the candidate-centeredness of the system. We have already discussed how small parties, such as the Socialists, responded to the formal rule of a 10 percent threshold for dual-listed seats by listing placeholder candidates. Japan's larger parties are not affected by this formal rule, but electoral competition also puts pressure on them to list placeholder candidates. Specifically, the LDP and the Democratic Party of Japan (DPJ) face a similar problem to the small parties when they win a landslide election. Because Japan's party-list tier is relatively large, a major party can win a significant number of seats on each of the party lists in Japan's eleven regions. Because dual-listed candidates are removed from the party list if they win a district seat, a party in a good electoral year can run out of names on its party lists. For example, if all of the dual-listed candidates in a region win their district races, all of their names will be removed from the party list. To fill the seats that the party will also win on the party list, parties put placeholder candidates on the bottom of their party lists. These candidates have no chance for victory unless the party wins a landslide election. Thus, the LDP has won landslide victories in 2005, 2012, and 2014 and has elected

\footnotetext{
${ }^{8}$ Shadow governments are a new phenomenon in Thailand and currently have no legal status as do shadow cabinets in the United Kingdom.

${ }^{9}$ PPP's first prime minister following the 2007 elections, Samak Sundravej, had been disqualified by the Constitutional Court on the grounds of violating the conflict of interests law.
} 
Table 2. The ratio of district- and list-reliant MPs in the Democrat Party's shadow cabinet.

\begin{tabular}{lcccccc}
\hline & Districts & $\begin{array}{c}\text { PR } \\
\text { Lists }\end{array}$ & Non-MPs & $\begin{array}{c}\text { Total } \\
\text { Cabinet } \\
\text { Positions }\end{array}$ & $\begin{array}{c}\text { District/ } \\
\text { PR Ratio }\end{array}$ & $\begin{array}{c}\text { District/Total } \\
\text { Positions } \\
\text { Ratio }\end{array}$ \\
\hline $\begin{array}{l}\text { Democrat Party, } \\
\text { Feb. 2008 - }\end{array}$ & 18 & 15 & 4 & 37 & 1.2 & 0.49 \\
$\begin{array}{l}\text { Dec. 2008 } \\
\begin{array}{c}\text { Democrat Party, } \\
\text { Aug. 2011 - } \\
\text { May 2014 }\end{array}\end{array}$ & 2 & 18 & 17 & 37 & 0.12 & 0.05 \\
\hline
\end{tabular}

thirteen, seventeen, and eleven placeholder candidates in each election respectively. Similarly, the Democrats elected forty-four placeholder candidates in their 2009 landslide. These placeholder candidates have become the dominant category of list-reliant victors in Japan's major parties. For example, seventeen of the eighteen list-reliant victors in the LDP in 2012 were also placeholder candidates.

Both types of placeholder candidates are significant, because most Japanese parties give these MPs almost no status or power. These weakest of the various types of MPs, however, constitute the majority of the small and shrinking cohort of list-reliant MPs that are elected to Japan's legislature. To illustrate the low political salience of these placeholder candidates, of the seventy-four placeholder candidates elected from 2005 to 2012 , only six have been reelected. Twenty-seven ran again as placeholder candidates (and four of these were reelected when the LDP won back-to-back landslide victories in 2012 and 2014). Thirty-two ran in district races. If placeholder candidates are excluded from calculations, 85.4 percent of Japan's MPs were district reliant in 2005, rising to 90.6 percent in 2009, 89.8 percent in 2012, and 89.7 percent in 2014.

Table 3 shows how parties have hardened in these preferences over time, with the centralized Komei and Communist parties becoming more list reliant and the decentralized LDP, Democrat, and Socialist parties becoming more district reliant. ${ }^{10}$

Party practices regarding the nomination procedure further illustrate the low hierarchy of PR list MPs. For the LDP and the Democrats, a favored position on the party list is typically used as a one-time reward for certain politicians (Reed 1995). In the long run, however, such politicians are expected to win their own reelection in a district and not continue to rely on favorable placement on the party list. In contrast, the Komei and Communist parties consistently give safe-list positions to their most influential MPs,

\footnotetext{
${ }^{10}$ The numbers reported in table 3 include placeholder candidates that inflate the numbers of list-reliant MPs for the Democrats in 2009, for the Socialists in 2005 and 2009, and for the LDP in 2005, 2012, and 2014. In 2012 and 2014, several new parties emerged that won seats. Two of the new parties (Mirai and Minna no to) followed the Socialists' example, electing nearly all their candidates as district-reliant victors. The Isshin no Kai initially struck a middle position, electing 37.5 percent of its MPs as list-reliant victors in 2012, but switched to reliance on district races for nearly all of its victors in 2014 .
} 
Table 3. Percent of list-reliant MPs in Japan.

\begin{tabular}{rrrrrr}
\hline & LDP & DPJ & Socialist & Komei & Communist \\
\hline 1996 & 18.8 & 29.4 & 26.7 & 37.5 & 92.3 \\
2000 & 22.3 & 15 & 5.3 & 74.2 & 100 \\
2003 & 15.6 & 2.3 & 0 & 73.5 & 100 \\
2005 & 14.5 & 2.6 & 28.6 & 73.3 & 100 \\
2009 & 9.2 & 14.3 & 14.3 & 100 & 100 \\
2012 & 6.1 & 0 & 0 & 71 & 100 \\
2014 & 5.5 & 1.4 & 0 & 74.3 & 71.4 \\
& & & & & \\
\hline
\end{tabular}

ensuring their continued reelection. Table 4 shows how these different nomination patterns have become more established over time.

Japan's two centralized political parties increasingly renominate list-reliant victors to safe positions on the party list (positions won by the party in multiple, consecutive elections). Thus, senior and influential members of these two parties will tend to be list-reliant MPs. In contrast, Japan's decentralized parties, including the two major political parties, renominate fewer and fewer list-reliant MPs to safe positions on party lists. Rather, these MPs are forced to run for reelection as district-reliant MPs. Thus, In Japan's two major parties, it is impossible to gain seniority and be eligible for a cabinet position without winning all or most elections as a district-reliant MP. Because the government is dominated by the two major parties, nearly all of the positions of significant power in Japan are also occupied by district-reliant MPs.

For example, only 112 politicians won seats in the five consecutive elections held from 1996 to 2009. Eighty-six were district-reliant MPs in all five elections, and all eightysix came from the LDP, the Democrats, or independent or minor parties. Thirteen were list-reliant MPs in all five elections, and all thirteen came from the Komei or Communist parties. The remaining thirteen (from the LDP and the Democrats) won a mixture of types of races, skewed towards district-reliant rather than list-reliant victories. ${ }^{11}$

The final party practice we discuss is the assigning of cabinet positions. We have already done this for Thailand in the context of the cabinet rule and political events, but reiterate here that this was a party choice based mostly on competitive pressures. Similarly, in Japan the two major parties, the LDP and the DPJ, have chosen increasingly more candidate-centered cabinets since electoral reforms. This increase has been a natural response to the decrease in list-reliant MPs as described above. However, the difference between list-reliant Diet members and cabinet members is notable. The result is that nearly all political power is in the hand of politicians who owe their election to how well they did in a district race. ${ }^{12}$

\footnotetext{
${ }^{11}$ Eight of the thirteen won four of their five races as district-reliant victors. Only one candidate each won three or four of their five races as list-reliant victors. Pekkanen, Nyblade, and Krauss (2006) conducted a similar analysis and found that seniority helps explain which MPs occupy committee leadership positions. We add that party nomination policies determine seniority, indirectly making party nomination policies an important explanation of which type of politicians become party leaders.
} 
Table 4. Percent of list-reliant MPs running for reelection on safe-list position, Japan.

\begin{tabular}{rrrrr}
\hline & LDP & Democrat & Komei & Communist \\
\hline 2000 & 44.4 & 33.3 & 47.5 & 58.3 \\
2003 & 25 & 5.3 & 73.9 & 40 \\
2005 & 27 & 25 & 84 & 88.9 \\
2009 & 11.6 & 0 & 81.8 & 88.9 \\
2012 & 9.1 & 0 & 57.1 & 88.9 \\
2014 & 5.6 & 0 & 100 & 83.3 \\
& & & & \\
\hline
\end{tabular}

Table 5 compares the percent of list-reliant members in the Diet and cabinet. It still exaggerates the influence of list-reliant MPs in Japan's cabinets because it ignores the past and subsequent elections of a cabinet member who happened to be given a safe-list seat as a one-time dispensation. Of the 344 MPs who served in a cabinet position from 1996 to 2015 , eighteen were list reliant (5.2 percent), but only six of the 344 (1.7 percent) were list reliant in both the preceding and subsequent elections. Four of these six were from the Komei Party, one was a cabinet member who only served one term in office, and the final list-reliant cabinet member was an LDP veteran who was favorably placed on the party list for his last three elections after having previously won district races in the five previous elections. Despite the fact that nearly 40 percent of Japan's lower house is elected from party lists, in practice all political power is concentrated in the hands of the district-reliant MPs that dominate Japan's two major political parties.In sum, the combination of idiosyncratic rules and party practices in response to the political climate, electoral competition, and other rules resulted in two different paths for Japan and Thailand's otherwise highly similar electoral reforms. Having established that political leaders in Japan are almost exclusively district reliant and that most of Thailand's political elites are elected from party lists, we now turn to an analysis of the actual policies enacted by the governments.

\section{The Composition of Public Spending in Japan and Thailand}

We now proceed to test the policy effects of candidate-centered MPs and leaders on the extent to which politicians engage in pork-barrel spending. Of course, candidatecenteredness can and does take different forms in different countries and may involve clientelism, particularism, or personalism. A country's MPs can engage in particularism, for example, without spending any money on pork-barrel projects, such as constituency service, direct benefits to specific groups, and direct payments to individuals. For this reason, we examine the two countries separately. We start with Japan, the more difficult of the two cases.

The literature on Japan makes a clear distinction between different forms of candidate-centeredness. McElwain (2012) and Reed, Scheiner, and Thies (2012) both provide strong, indirect evidence of the decline in what they call "particularism." Using measures of incumbency advantage, partisan swings, party platforms, candidate 
Table 5. Percent of list-reliant Japanese cabinet and Diet members.

\begin{tabular}{|c|c|c|c|c|c|c|c|}
\hline & \multirow{2}{*}{$\begin{array}{c}\text { Diet } \\
\text { Percent }\end{array}$} & \multicolumn{6}{|c|}{ Cabinet } \\
\hline & & $\begin{array}{l}\text { District } \\
\text { Reliant }\end{array}$ & $\begin{array}{l}\text { PR List } \\
\text { Reliant }\end{array}$ & Non-MPs & $\begin{array}{l}\text { Total Cabinet } \\
\text { Positions }\end{array}$ & $\begin{array}{l}\text { District/PR } \\
\quad \text { Ratio }\end{array}$ & $\begin{array}{l}\text { District/Total } \\
\text { Positions Ratio }\end{array}$ \\
\hline $\begin{array}{l}\text { Liberal Democrat Party, Oct. } \\
1996 \text { - Jun. } 2000\end{array}$ & 29.4 & 43 & 5 & 12 & 60 & 8.60 & 0.72 \\
\hline $\begin{array}{l}\text { Liberal Democrat Party, Jun. } \\
2000 \text { - Nov. } 2003\end{array}$ & 27.3 & 37 & 6 & 11 & 54 & 6.17 & 0.69 \\
\hline $\begin{array}{l}\text { Liberal Democrat Party, Nov. } \\
2003 \text { - Sept. } 2005\end{array}$ & 15.6 & 22 & 3 & 6 & 31 & 7.33 & 0.71 \\
\hline $\begin{array}{l}\text { Liberal Democrat Party, Sept. } \\
2005 \text { - Aug. } 2009\end{array}$ & 14.6 & 56 & 3 & 14 & 73 & 18.67 & 0.77 \\
\hline $\begin{array}{l}\text { Democrat Party Japan, Aug. } \\
2009 \text { - Dec. } 2012\end{array}$ & 9.4 & 44 & 0 & 18 & 62 & 44.00 & 0.77 \\
\hline $\begin{array}{l}\text { Liberal Democrat Party, Dec. } \\
2012 \text { - Dec. } 2014\end{array}$ & 10.2 & 27 & 0 & 6 & 33 & 27.00 & 0.82 \\
\hline $\begin{array}{l}\text { Liberal Democrat Party, Dec. } \\
2014 \text { - Dec. } 2015\end{array}$ & 10.3 & 23 & 1 & 7 & 31 & 23.00 & 0.74 \\
\hline
\end{tabular}


characteristics, and urban-rural differences, they link the changes in electoral rules to declines in particularism. Other scholars, however, have directly studied pork-barrel spending. In addition to the effect of electoral system changes on pork-barrel spending (Hirano 2006; Naoi 2015; Noble 2010), scholars have also explored pork-barrel spending's relationship to LDP dominance of Japanese elections (Scheiner 2006), committee assignments (Pekkanen et al. 2006), reapportionment (Horiuchi and Saito 2003), and party defections (Saito 2009).

Despite all of these studies, there is mixed evidence on whether or not pork-barrel spending remains an important factor in Japanese politics. Part of the confusion stems from the fact that pork-barrel spending, relative to other types of government spending, has been declining in Japan for more than forty years. In addition, many other factors can affect levels of pork-barrel spending. Noble (2010), for example, documents the decline in relative pork-barrel spending after electoral reform, but he includes the reforms as only one of six possible causes of the decline, also citing international financial constraints, a struggling domestic economy, an aging society, changes in public support for pork-barrel spending, and administrative reforms.

Reed et al. (2012, 360-61) cite Noble's work approvingly and agree that disentangling the different possible causes of this decline in pork-barrel spending is a difficult task. They find that personalistic characteristics of candidates are less important to voters than they have been in times past and candidates are placing less emphasis on the concerns of rural voters. Both of these studies claim that electoral reforms affected pork-barrel spending, but they both hedge this claim by recognizing the other factors that also likely affect this spending.

In contrast, other authors suggest that pork-barrel spending continues to play an important role in Japanese politics. Hirano (2006) notes a change in the geographic concentration of spending as multi-seat districts changed to single-seat districts, but suggests that pork-barrel spending still occurred, simply shifting from targeting hometowns to targeting the larger district. Naoi $(2015,95-102)$ presents the strongest evidence that porkbarrel spending was still strong post-1994. In the larger context of developing a theory of how pork-barrel spending can be used to secure legislative support for trade liberalization legislation, she finds no significant effect of electoral reform on levels of this spending in Japan.

We add several pieces of evidence that help disentangle the effect of electoral rule change on pork-barrel spending. First, the relative decline in this spending that some scholars have noted since the 1990s actually began in the 1970s. Using what Scheiner $(2006,86)$ suggests is the best measure of pork-barrel spending, the category of "public works" as a percent of national government spending, figure 1 shows that pork's relative share of government spending began declining in 1972, two decades before the electoral reforms. ${ }^{13}$ This finding adds weight to the numerous factors cited above by Noble (2010), and not the change in electoral rules, that led to a relative decline in public works spending. In fact, the post-1993 decline only comes after a

\footnotetext{
${ }^{13}$ The Japanese government includes the following spending in its "public works" category: roads, harbors, airports, railways, housing, sewers, and waste water construction; spending on forest and river conservation, agriculture and agricultural areas, and urban areas; improvements to fisheries and forests; and rebuilding after natural disasters.
} 


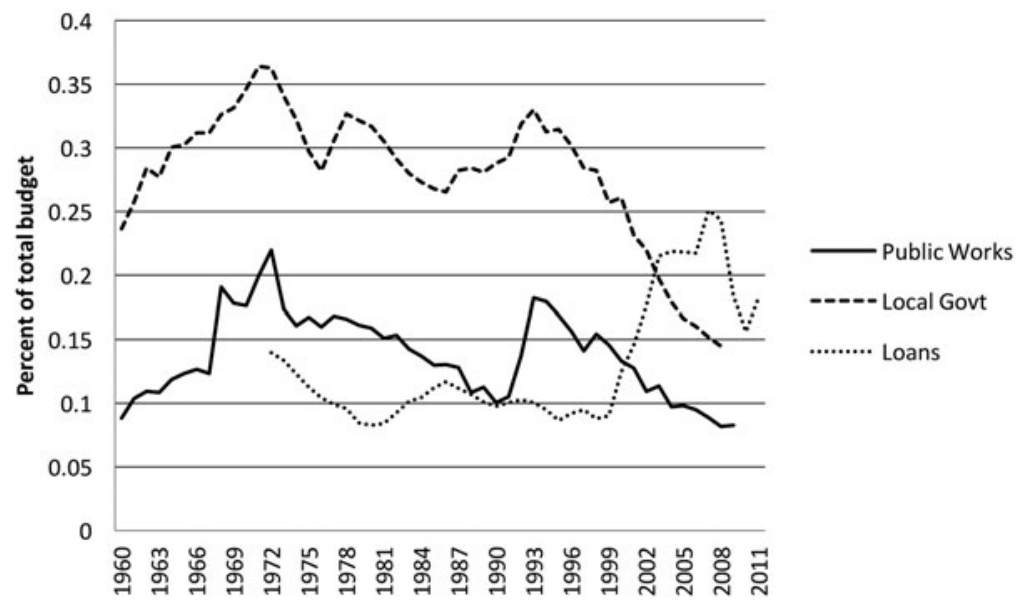

Figure 1. Three measures of public works spending in Japan.

spike in spending in 1991, made in an effort to stimulate the Japanese economy. It takes almost fifteen years to get back down to the pre-spike levels. Indeed, the 1993-2003 average is actually higher than the 1972-1992 average. This higher spending average cannot be due to higher levels of government revenue, as average GDP growth rates were actually lower for the 1993-2003 period than for the prior two decades. This first piece of evidence, then, leads us to conclude that pork-barrel spending as a ratio of government spending actually went up slightly in this period.

A second piece of evidence that places doubt on electoral reform decreasing porkbarrel spending emerges when we compare spending at the national and local levels. Figure 1 shows that the share of local government spending on public works also declined during the same period. Comparing national and local government spending on public works allows us to conduct a natural experiment of sorts that controls for all of the other possible factors that could affect such spending while only contrasting the effect of changing the electoral system. This natural experiment is made possible because Japan's electoral reform in 1994 changed the election districts for only the national legislature. Japan's provincial assemblies continued to be elected by a mix of election districts, skewed heavily toward multi-seat districts. For example, in 2012, 82.8 percent of all Japan's provincial legislators were elected from multi-seat districts, similar to the election system used for Japan's national legislature prior to 1994.

This comparison, reported in figure 1 , shows that public works spending has been declining since about 1972 at both the national and local government levels. This, by itself, is strong evidence that electoral rules were not responsible for the relative decline in pork-barrel spending. However, we also see that the decline in local government public works spending was actually steeper than the similar decline in national government spending since the stimulus efforts of the early 1990s. If the reform of the national election system was one of the causes of this decline, why would it affect porkbarrel spending at the local level of government where the electoral rules remained the same? We think the most likely story, consistent with our hypothesis that the effect of electoral reform did not change the district reliance of Japanese MPs, is that as the 
overall government budget got squeezed, national politicians did all they could to preserve their pork-barrel spending power by cutting local public works budgets first. An alternative explanation is that public works spending is not affected at all by electoral incentives. This conclusion would be especially problematic for accounts of Japan's electoral reform that posit a decrease in particularism. However, the patterns are consistent with our story of the electoral reform being undermined by a "best loser" provision designed by strategic politicians who had interests in maintaining the status quo.

A fair counterargument is that it takes time for the effect of electoral rules to take place and that the post-1993 decline in public works spending we observe reflects this gradual process. If, however, politicians, as we argue, still had strong incentives to engage in such spending, perhaps they would have turned to other sources to fund their pork. Another method to fund pork-barrel project are loans. "Public works" in figure 1 does not include loans that might also be allocated to pork-barrel projects. The dotted line in figure 1 reports the percent of total fiscal investments and loans (at the national level) allocated to the categories of roads and local area development. ${ }^{14}$ The ratio of loans going to these categories has been at unprecedentedly high levels for the past decade or so — exactly when public works spending declined. Indeed, porkbarrel spending through government loans is actually alive and well, despite the shrinking amount of money available through such loan programs. ${ }^{15}$

Our discussion of both loans and public works spending has been about the ratios of such spending as a percent of a larger pot of money controlled by the government. Only discussing the share of government spending allocated to pork-barrel type projects rather than looking at other comparisons or the absolute amount of spending can be misleading. For example, the amount of public works spending is actually at higher levels in the five most recently reported years (2005-9) than it was in the five years immediately prior to the stimulus surge in infrastructure spending. ${ }^{16}$ It is also important to look at other ways of measuring pork, beyond the simple measure of public works, which can include personnel costs of certain government programs along with actual construction expenditures. Focusing more narrowly on the government's share or infrastructure's share of all construction spending shows that both have held constant for decades, despite the ups and downs of the ratio of public works spending as a share of total government spending. The national government's share of total construction spending in Japan (the dotted line in figure 2) has been stable at 10 to 15 percent since the mid-1980s. Similarly, infrastructure's share of all construction spending has also remained constant in Japan since the beginning of the 1970s.

In sum, we agree with Naoi (2015) that pork-barrel spending has continued strongly after the constitutional reforms. By looking at the long-term trends, it becomes clear that

\footnotetext{
${ }^{14}$ All of our measures of spending for figures 1 and 2 come from Japan Statistical Yearbook (19602015), tables 9-1, 9-2, 9-3, 5-4, 5-12, and 5-9.

${ }^{15}$ The total amount of loans in in 2011 was only 28 percent of the total of the peak year for loans, 1999.

${ }^{16}$ From 1987 to 1991, the average annual government expenditure on public works was 7,169 billion yen per year. From 2005 to 2009 , this annual average increased to 7,726 billion yen per year. Even adjusting the earlier average for inflation raises the yearly average only to 7,831 billion yen per year, nearly identical to the average of the most recent years.
} 


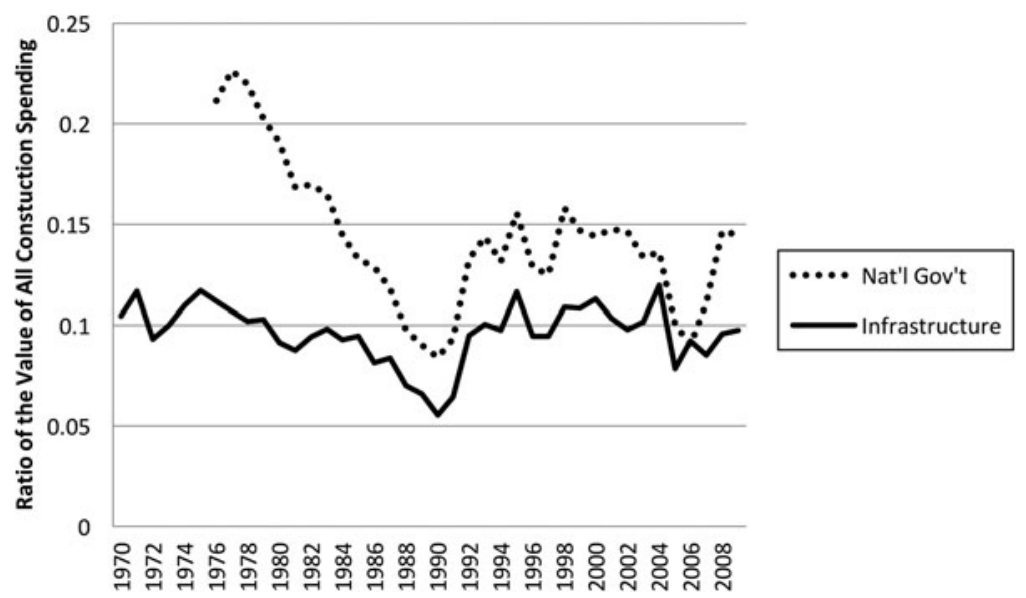

Figure 2. Two measures of total construction spending in Japan.

the decline predated the reforms. We put this down to demographic and economic pressures on the government budget. Indeed, declines in pork spending were observed at the provincial level where the same electoral system remained in place. Instead, we see politicians turning to alternative sources of funding for pork-barrel projects, most notably loans.

In contrast to Japanese spending, we find that pork-barrel politics in Thailand has severely declined since the electoral reform in 1997. The literature here is much thinner compared to Japan, but also much clearer in its conclusions. This decline in porkbarrel spending is most easily seen by looking at the "Investment" portion of the Thai budget, which mainly consists of spending on construction, property, and equipmentthe perfect kinds of pork-barrel goods. Figure 3 displays the percent of total government spending on investment. First, note the spike between 1988 and 1997. The position of prime minister, and along with it full control of the budget, was first given to elected politicians in 1988 (Hicken 2004). We then see a dramatic drop following the 1997 change in electoral rules. Although there was a severe financial crisis in Thailand in 1997, it is interesting to note that spending on construction, property, and equipment remained at high levels until after the first elections of 2001. That it dropped slowly is more indicative that the electoral rules took time to take root rather than the drop being a result of the crisis. If the latter were true, we would have expected to see a much sharper drop in the year immediately following the crisis and then a return to higher levels as the economy rebounded, which it did within a couple of years. Over a decade later, the investment proportion of the budget remains at record lows.

Other scholars have noted this dramatic change in the composition of government spending in Thailand following the electoral reform. Selway (2011) notes that this same pattern of spending can be observed in the Ministry of Public Health's (MOPH) budget, perhaps one of the most pork-ridden ministries in Thailand in the pre-1997 era. Table 6 displays these results. Reaching a peak in 1997 of 38.7 percent of the MOPH budget, spending on construction almost ground to a halt, reaching a low of 4.4 percent in 2003. Selway's analysis stops in 2004, but over the next eight years we can see that spending levels have remained low. The investment portion of the MOPH 


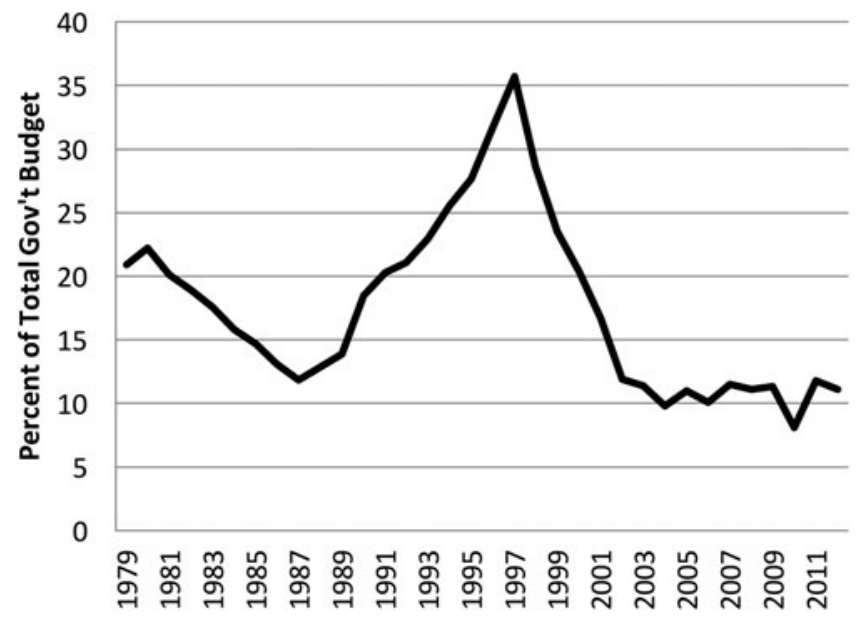

Figure 3. Spending on construction, property, and equipment, percent of Thai government budget.

dropped as low as 1.9 percent of the ministry's budget in 2010, though this drop seems to have been compensated for with a post-electoral reform high of 16 percent in the following year. The average investment portion of the MOPH budget was 21.8 percent prior to electoral reform compared to 6.1 percent following the first elections.

Naoi $(2015,114)$ also notes that the change in electoral rules "facilitated the government's shift from Pork to Policy." Using a measure of the proportion of government expenditures dedicated to social protection (such income protection, welfare, and healthcare), she finds that the post-2001 era represented a shift to "universalism, rather than parochialism" (114). Naoi's study is also of note since it is the only other study we are aware of that explicitly compares Japan and Thailand and considers the effect of electoral rules.

\section{Electoral Reform in JaPAn and Thailand}

Country-specific electoral rules and party practices have produced radically different outcomes in public works spending, the composition of party leaders and cabinets, and the composition of legislatures, but the question remains why Japan and Thailand went down such radically different paths after having a long period of similarity in policy outcomes, electoral incentives, and legislative cultures. A key feature in explaining the Japanese outcomes is the "best loser" provision coupled with the decision by most Japanese parties to use this provision. These decisions converted most MPs and nearly all cabinet members into politicians who are candidate-centered rather than party-centered.

Japan's "best loser" provision is rare, even among countries with mixed electoral systems that allow dual listing. Perhaps the Italian senate is the only other legislative body that has had such a provision. It is not surprising, therefore, that the "best loser" provision developed among Japanese MPs rather than being copied from another 
Table 6. Ministry of Public Health budget by allocation percent. Sources: Selway (2011) and Thailand Budget Bureau (2005-12). Note: Line represents first budget made under new electoral rules.

\begin{tabular}{lrrr}
\hline & Salaries & Operating & Investment \\
\hline Average, 1979-1997 & 43.94 & 34.32 & 21.84 \\
High, 1979-1997 & 33.5 & 27.8 & 38.7 \\
1998 & 38.5 & 34.2 & 27.3 \\
1999 & 44.6 & 40.2 & 15.2 \\
2000 & 46.8 & 41.7 & 11.5 \\
2001 & 47.2 & 44 & 8.8 \\
\hline 2002 & 41.7 & 50.4 & 7.9 \\
2003 & 44.6 & 51 & 4.4 \\
2004 & 44.6 & 48.7 & 6.7 \\
2005 & 77.3 & 15.2 & 2.8 \\
2006 & 81.5 & 11.2 & 3.2 \\
2007 & 76.3 & 13.2 & 3.5 \\
2008 & 76.6 & 13.0 & 5.2 \\
2009 & 76.4 & 12.7 & 5.5 \\
2010 & 77.7 & 15.5 & 1.9 \\
2011 & 65.3 & 13.0 & 16.0 \\
2012 & 68.2 & 16.0 & 10.3 \\
Average, 2002-2012 & $\mathbf{6 6 . 4}$ & $\mathbf{2 3 . 6}$ & $\mathbf{6 . 1}$ \\
& & & \\
\hline
\end{tabular}

country's electoral system. The idea for the "best loser" provision developed out of the election practices and weak party organizations that were already in place under the old electoral system. The rule was first included in a 1964 electoral reform commission report. The report proposed allowing parties to allocate seats on the party list at the same position, making it possible for parties to use performance in a district race as a tie breaker (Asahi shinbun 1964; Reed and Thies 2001). When electoral reform became a topic of discussion again in the 1990s, the "best loser" provision was again included in a subsequent electoral reform commission's report, and then both the ruling coalition and the opposition party included the rule as part of their competing bills for electoral reform.

It does make sense that in a highly candidate-centered electoral system, setting aside a smaller number of seats for party lists would lead naturally to the expectation that dual listing would be allowed so that some of the district losers could still win seats based on the popularity of their parties. In deciding who those party-list winners should be, it is no wonder that the idea occurred and was immediately supported of allocating these "second chance" seats not by a central party decision but as a reward for candidate performance. Such an approach might have seemed odd in a country with strong political parties that tightly controlled candidate nominations. In Japan, however, the LDP and some of the opposition parties of the time had extremely weak party organizations, even allowing nominations to be controlled by local politicians and faction leaders. Given these facts, it made intuitive sense that Japanese parties were allowed to determine their party-list winners in a decentralized manner: by the results of district races. 
In fact, this provision was not even discussed in the multi-year process of electoral reform in Japan. The focus of electoral reform efforts was to create incentives for the opposition parties to unite, forming a viable alternative to the seemingly invincible rule of the LDP. In addition, reformers hoped to create elections in which winning parties won victories that were more decisive, giving a winning party a mandate for policy change rather than the more muddled electoral outcomes that resulted from Japan's previous system of multi-member districts. Both of these goals were accomplished by the change to single-member districts. In order to ensure the support of some of the opposition parties, though, the effect of the single-member districts had to be tempered with an allocation of seats to party lists to make sure that smaller parties could still exist under the new electoral system. Thus, Japanese reformers embraced a mixed electoral system. To further enhance the prospects for passage, reformers also promised to cut campaign spending and corruption as well as to create harsher penalties for violations of campaign finance laws. The discussion of issues in campaigns was also promoted by enhancing the role of the party in campaigns. Not only was there a new party-list vote, but also a national subsidy of political parties was created. Some of these reforms were primarily window dressing to enhance the appeal of the entire electoral reform package. Even at the time of passage, reformers did not expect the reforms to actually change the quality and character of campaigns significantly, especially with regard to campaign spending and corruption (Christensen 1994).

Thus, because the real focus of reform efforts in Japan was to combine the opposition parties into a viable alternative party, the "best loser" provision, which undercut many of the incentives for party-list candidates to pay attention to national issues rather than district issues, was included in the reforms without any discussion or opposition. Its inclusion was not a stealth effort to undercut some of the intended reforms. Rather it was an obvious way to allocate party-list positions in a decentralized fashion, in common with the long-standing, decentralized candidate selection practices of the LDP, Socialist, and Democratic Socialist parties. In fact, it is not surprising that the two parties that do not use the "best loser" provision, the Communists and the Komei Party, are the parties that traditionally had centralized candidate selection procedures, even under the old electoral system.

The choice of whether or not to use the "best loser" provision simply allowed each party to decide its party-list positions in the same manner as it had always decided nominations, suggesting that party practices determined the institution, in this example, rather than the institution affecting party practices. This outcome was possible in Japan because the demand for reform was weak and largely unfocused (Christensen 1994; Reed and Thies 2001), giving Japanese politicians the leeway to shape parts of the reform in a way that was consistent with existing practices and congruent with the preferences of most individual politicians.

Like politicians in Japan, Thai politicians had some involvement in the new Constitution and electoral rules that came about in 1997 (McCargo 2002). They not only approved the members of the constitutional drafting assembly, but also attempted to influence the process afterwards (Wasi 2002). However, Thai politicians were mostly sidelined during the process, suffering from a severe loss of legitimacy due to the recent financial crisis. We should thus first look to the preferences of existing politicians to understand why we observe the divergent outcomes in the similar-looking mixed 
electoral systems that were created. Like in Japan, the Thai electoral reform process was focused on creating a two-party system; however, in contrast to Japan, Thailand was attempting to forge such a system from a highly fractionalized system. There was no equivalent of the LDP - a dominant party that had won every election since World War II-in Thailand. Thus, although Thai politicians, like their Japanese counterparts, were strong district MPs who had relied on pork-barrel goods for years, there was no single entity looking to protect a historic advantage. All the Thai parties, ostensibly, would be on the same footing under the new rules. Nevertheless, some parties attempted to disrupt the drafting process and sabotage attempts to introduce reforms (Wasi 2002). They were met, however, by strong public participation spurred in part by the 1997 financial crisis.

The one exception is perhaps the Democrat Party. Since 1979, their electoral success had increased from around 15 percent to just over 30 percent in the 1996 elections. Despite a clear concentration of strength in the south, the Democrats were the most geographically widespread in terms of both party offices and electoral candidates. If any party had any incentive to push for a mixed system that was dominated by the party-list tier, it would be the Democrat Party. Moreover, the Democrats led the government at the time of the crisis. Following the resignation of Chavalit Yongchaiyudh in the wake of the financial crisis, Chuan Leekpai took over as prime minister, and his Democrat Party was generally regarded as a moderate, technocratic party at the time. It is unclear if the Democrat Party had much influence on the process, but to the extent that it did, it pushed in the same direction as public sentiment, which pushed in the opposite direction compared to Japan's reforms.

Societal interests, however, were much more dominant in the Thai electoral reform process. The financial crisis was the country's worst to date; years of economic success came abruptly to a halt for millions of Thais who were left with no social safety net (Pasuk and Baker 2000). Nongovernmental organizations and grassroots citizens groups protested against the failure of the social contract (Hewison 2004) and were involved in the drafting of the new Constitution (Doneys 2002; Ockey 2002; Phatharathananunth 2002; Thabchumpon 2002). One of the main targets in the reform process was the party system. Thais blamed the parties for not only the financial crisis but also the excesses of the past two decades. Vote buying, pork-barrel politics, and outright corruption tainted the public perception of political parties, and many of the rules were specifically designed to prevent small parties from arising: a 5 percent threshold for the party-list tier, the losing of one's parliamentary seat when joining the cabinet, and a rule prohibiting party switching ninety days prior to an election (Chantornwong 2002). Responsible national parties constituted the war cry of the day.

However, as if not enough to change the characteristics of the policymakers, the Thai Constitution went even further to specify the types of policies that should be enacted. The right to receive public health services (article 52) and enjoy a healthy environment (article 56) are specifically mentioned, for example, in chapter III of the Constitution and then repeated as directive principles of fundamental state policies in chapter $\mathrm{V}$, articles 79 and 82. Similar rights were delineated in the education sector, and specific rights for children, the elderly, and the handicapped were also included. As such, the 1997 Thai Constitution was hailed as one of the most progressive to date. These specific rights put 
pressure on parties to formulate national programmatic policies, thus further emphasizing the primacy of the party list.

\section{Conclusion}

We set out to explain the divergent paths that Thailand and Japan's seemingly similar electoral systems took in terms of how candidate- versus party-centered they were. Both Thailand and Japan adopted unlinked mixed systems with similarly sized proportions of their MPs being elected from party lists. Thailand's reforms resulted in a system dominated by MPs elected from party lists and thus a much more party-centered system; Japan remains dominated by district MPs. These differences affected the policies that were enacted in the post-reform era. Thailand had a huge increase in the amount of nationally oriented public goods; Japan saw the continuation of particularistic spending and pork-barrel politics.

None of the common features of mixed systems can explain this divergence, not even the fact that Japan allowed dual listing. Rather, in both countries, the historical trajectory prior to the electoral reform and the social, political, and economic environment at the time of the reform led to idiosyncratic rules and party practices in both countries that pushed the systems in opposite directions. In Japan, the reform process came in the context of the historical dominance of the LDP and was more the result of an opportunistic move by LDP rebels working with the opposition parties to create a two-party system. In Thailand, the reform process came about in the context of a highly fractionalized party system, though the goal was also to create a two-party system. Perhaps more importantly, Thailand's opportunity that created the push for reform was the country's worst financial crisis to date that left millions of Thais with no social safety net. Public participation was thus high and prevented parties from shaping the rules in ways that would protect their current interests.

These contexts help explain the specific rules that have shaped the outcomes we see today. In Japan, the seemingly benign dual-listing rule was combined with a "best loser" provision that all of the parties with weak organizational structures used to determine nearly all of their party-list winners. These parties' decision to use this rule resulted in most Japanese MPs on the party list behaving just like district MPs. In contrast, in Thailand, a slew of additional rules, such as the 5 percent threshold, the rule on cabinet members, and the party-switching rule, as well as specific rights listed in the Constitution for public goods, all served to strengthen the role of the party vis-à-vis individual MPs.

This analysis suggests that comparing mixed systems along the common features of linkage, tier ratio, and dual listing is insufficient and perhaps even misleading. We find that small, idiosyncratic rules and party practices are equally, if not more, important in shaping outcomes. Moreover, these rules and practices are a result of the reform process. The motivations of those who were in control of the reform process tended to produce a mixed system that matched their preferences. Our findings comport with those who have found high levels of uncertainty about the actual outcomes when politicians draft new electoral rules (Kaminski 2002; Moser 2001) and those who have found that both the causes and the effects of electoral rule changes are dependent upon the political context in which the changes were made (Benoit 2007; Carstairs 1980; Moser 
2001) Our findings also support those who have called for a greater inquiry into the causes of institutional change along with the well-developed literature on the effects of institutional changes (Benoit 2007; Boix 1999; Rodden 2009).

Our results have also showed the opaque nature of causal inquiries, especially when the institutions are as complex as they are in mixed electoral systems. This causal complexity makes it even more crucial to analyze the reasons for the enactment of electoral reforms to better understand the likely effects of the reforms rather than just relying on predictions based on electoral institutions operating under less complex electoral rules. We conclude with the speculation that perhaps this complexity itself is one reason why mixed electoral systems are popular with electoral reformers. The variety of rules and party practices that are possible under a mixed electoral system gives politicians greater leeway to shape (or attempt to shape) the outcomes of electoral reform efforts than they would have under a system of simpler electoral rules.

We began this article by referencing the historic constitutional reforms in Japan and Thailand, with a main goal in both efforts being the development of more programmatic parties that would eliminate pork-barrel politics and crony capitalism. Both worthy goals, these efforts were significantly hampered in Japan due to politicians protecting entrenched interests. In contrast, in Thailand the new electoral rules severely threatened established parties. The rise of TRT with huge support from rural areas, especially in the north and northeast regions, was met with huge dissatisfaction by the previous largest party, the Democrat Party, which was unable to match TRT's policy innovativeness. The Democrat supporters, generally middle- and upper-class citizens from the capital Bangkok, instead turned to mass street protests to have their interests heard. The Thai story, then, provides warnings for rules that ignore the preferences of existing elites. If too heavily sidelined, they and their supporters may turn to less democratic means to have their voice heard. Street protests have been followed by two coups, each taking out TRT and its successor parties, and seemingly aimed at placating Democrat interests. Democracy itself has been the ultimate victim of constitutional reforms in Thailand that were initially hailed for their progressiveness. If this was the tradeoff, many Thais in hindsight might have opted for more pork-barrel politics over the loss of democracy. In any constitutional reform effort, then, buy-in from existing elites should be a point of consideration. Slow and incremental improvement is preferable to rapid shake-ups that undermine the entire reform enterprise.

\section{List of References}

Alesina, Alberto, and Edward Glaeser. 2004. Fighting Poverty in the US and Europe: A World of Difference. Oxford: Oxford University Press.

ANFrel, The Asian Network for Free Elections. 2008. Thailand, Elections to the House of Representatives, 23rd December 2007: Report of the International Election Observation Mission. Bangkok: ANFREL.

. 2011. Thailand General Election, 3rd July 2011: Report of the International Election Observation Mission. Bangkok: ANFREL. 
ASAHi SHINBUn. 1964. "Daisanji senkyo seidoshin ga saishū hōkoku" [The third advisory committee on electoral reform makes its final report]. August 26, 2.

Barker, Fiona, Jonathan Boston, Stephen Levine, Elizabeth McLeay, and Nigel S. Roberts. 2001. "An Initial Assessment of the Consequences of MMP in New Zealand." In Mixed Member Systems: The Best of Both Worlds?, eds. Matthew Soberg Shugart and Martin P. Wattenbert, 296-322. Oxford: Oxford University Press.

Batto, Nathan F. 2012. "Differing Mandates and Party Loyalty in Mixed-Member Systems: Taiwan as a Baseline Case.” Electoral Studies 31(2):384-92.

Benoit, Kenneth. 2007. "Electoral Laws as Political Consequences: Explaining the Origins and Change of Electoral Institutions." Annual Review of Political Science 10:363-90.

Blais, Andre, Agnieska Dobrzynska, and Indridi H. Indridason. 2005. "To Adopt or Not to Adopt Proportional Representation: The Politics of Institutional Choice." British Journal of Political Science 35(1):182-90.

Borx, Carles. 1999. "Setting the Rules of the Game: The Choice of Electoral Systems in Advanced Democracies.” American Political Science Review 93(3):609-24.

Carey, John M. 2007. "Competing Principals, Political Institutions, and Party Unity in Legislative Voting." American Journal of Political Science 51(1):92-107.

Carey, John M., and Matthew Soberg Shugart. 1995. "Incentives to Cultivate a Personal Vote: A Rank Ordering of Electoral Formulas." Electoral Studies 14(4):417-39.

Carstairs, Andrew McLaren. 1980. A Short History of Electoral Systems in Western Europe. Boston: George Allen and Unwin.

Chang, Eric C. C., and Miriam A. Golden. 2007. "Electoral Systems, District Magnitude and Corruption.” British Journal of Political Science 37(1):115-37.

Chantornwong, Sombat. 2002. "The 1997 Constitution and the Politics of Electoral Reform.” In Reforming Thai Politics, ed. Duncan McCargo, 203-22. Copenhagen: Nordic Institute of Asian Studies.

Christensen, Raymond V. 1994. "Electoral Reform in Japan: How It Was Enacted and Changes It May Bring." Asian Survey 34(7):589-605.

Colomer, Josep M. 2005. "It's Parties that Choose Electoral Systems (or, Duverger's Laws Upside Down)." Political Studies 53(1):1-21.

Crisp, Brian F. 2007. "Incentives in Mixed-Member Electoral Systems: General Election Laws, Candidate Selection Procedures, and Cameral Rules." Comparative Political Studies 40(12):1460-85.

Crisp, Brian F., and Scott W. Desposato. 2004. "Constituency Building in Multimember Districts: Collusion or Conflict?” Journal of Politics 66(1):136-56.

Curtis, Gerald L. 1971. Election Campaigning Japanese Style. New York: Columbia University Press.

Cusack, Thomas, Torben Iversen, and David Soskice. 2010. "Coevolution of Capitalism and Political Representation: The Choice of Electoral Systems." American Political Science Review 104(2):393-403.

Doneys, Philippe. 2002. "Political Reform through the Public Sphere: Women's Groups and the Fabric of Governance." In Reforming Thai Politics, ed. Duncan McCargo, 163-82. Copenhagen: Nordic Institute of Asian Studies.

Edwards, Martin S., and Frank C. Thames. 2007. "District Magnitude, Personal Votes, and Government Expenditures.” Electoral Studies 26(2):338-45. 
Ferrara, Federico. 2004. "Electoral Coordination and the Strategic Desertion of Strong Parties in Compensatory Mixed Systems with Negative Vote Transfers.” Electoral Studies 23(3):391-413.

Hallerberg, Mark, and Patrik Marier. 2004. "Executive Authority, the Personal Vote, and Budget Discipline in Latin American and Caribbean Countries." American Journal of Political Science 48(3):571-87.

Herron, Erik. S., and Misa Nishikawa. 2001. "Contamination Effects and the Number of Parties in Mixed Superposition Electoral Systems." Electoral Studies 20(1):63-86.

Hewison, Kevin. 2004. “Crafting Thailand's New Social Contract.” Pacific Review 17(4): $503-22$.

Hicken, Allen. 2002. "Parties, Pork and Policy: Policymaking in Developing Democracies." PhD diss., University of California, San Diego.

. 2004. "The Politics of Economic Reform in Thailand: Crisis and Compromise." William Davidson Institute Working Paper no. 638.

Hicken, Allen, and Joel Simmons. 2008. "The Personal Vote and the Efficacy of Education Spending." American Journal of Political Science 52(1):109-24.

Hirano, Shigeo. 2006. "Electoral Institutions, Hometowns, and Favored Minorities: Evidence from Japanese Electoral Reforms." World Politics 59(1):51-82.

Horiuchi, Yusaku, and Jun Saito. 2003. "Reapportionment and Redistribution: Consequences of Electoral Reform in Japan." American Journal of Political Science 47 (4):669-82.

Japan, Ministry of Internal Affairs and Communications, Statistics Bureau. 19602015. Japan Statistical Yearbook.

Johnson, Joel W., and Jessica S. Wallack. 2010. "Electoral Systems and the Personal Vote.” http:/hd1.handle.net/1902.1/17901 (accessed January 29, 2017).

Kaminski, Marex M. 2002. "Do Parties Benefit from Electoral Manipulation? Electoral Laws and Heresthetics in Poland 1989-1993." Journal of Theoretical Politics 14(3): 325-58.

Klingemann, Hans-Dieter, and Bernhard Wessels. 2001. "The Consequences of Germany's Mixed-Member System: Personalization at the Grassroots?" In Mixed Member Systems: The Best of Both Worlds?, eds. Matthew Soberg Shugart and Martin P. Wattenberg, 279-96. Oxford: Oxford University Press.

Lancaster, Thomas D. 1986. "Electoral Structures and Pork Barrel Politics." International Political Science Review 7(1):67-81.

Lancaster, Thomas D., and W. David Patterson. 1990. "Comparative Pork Barrel Politics: Perceptions from the West German Bundestag." Comparative Political Studies 22(4):458-77.

McCargo, Duncan. 2002. Reforming Thai Politics. Copenhagen: Nordic Institute of Asian Studies.

McElwain, Kenneth Mori. 2012. “The Nationalization of Japanese Elections.” Journal of East Asian Studies 12(3):323-50.

McKean, Margaret, and Ethan Scheiner. 2000. “Japan’s New Electoral System: La Plus ça Change..." Electoral Studies 19(4):447-77.

Moser, Robert G. 2001. Unexpected Outcomes: Electoral Systems, Political Parties, and Representation in Russia. Pittsburgh, Pa.: University of Pittsburgh Press.

Naoi, Megumi. 2015. Building Legislative Coalitions for Free Trade in Asia: Globalization as Legislation. Cambridge: Cambridge University Press. 
Nielson, Daniel L. 2003. "Supplying Trade Reform: Political Institutions and Trade Policy in Middle-Income Democracies.” American Journal of Political Science 47 (3):470-91.

Noble, Gregory W. 2010. “The Decline of Particularism in Japanese Politics.” Journal of East Asian Studies 10(2):239-73.

Ockey, James. 1994. "Political Parties, Factions, and Corruption in Thailand.” Modern Asian Studies 28(2):251-77.

—. 2002. "Civil Society and Street Politics in Historical Perspective." In Reforming Thai Politics, ed. Duncan McCargo, 107-24. Copenhagen: Nordic Institute of Asian Studies.

Pasuk Phongpaichit and Chris Baker. 2000. Thailand's Crisis. Bangkok: Silkworm Books.

Pekkanen, Robert, Benjamin Nyblade, and Ellis S. Krauss. 2006. "Electoral Incentives in Mixed-Member Systems: Party, Posts, and Zombie Politicians in Japan.” American Political Science Review 100(2):183-93.

Persson, Torsten, and Guido Tabellini. 2003. The Economic Effects of Constitutions. Cambridge, Mass.: MIT Press.

Phatharathananunth, Somchai. 2002. "Civil Society and Democratization in Thailand: A Critique of Elite Democracy.” In Reforming Thai Politics, ed. Duncan McCargo, 125-42. Copenhagen: Nordic Institute of Asian Studies.

Ragin, Charles C., and Howard Saul Becker. 1992. What Is a Case?: Exploring the Foundations of Social Inquiry. Cambridge: Cambridge University Press.

Reed, Steven R. 1995. “The Nomination Process for the Next General Election in Japan: Waiting for the Heiritsu-sei." Asian Survey 35(12):1075-87.

Reed, Steven R., Ethan Scheiner, and Michael F. Thies. 2012. "The End of LDP Dominance and the Rise of Party-Oriented Politics in Japan." Journal of Japanese Studies 38(2):353-76.

Reed, Steven R., and Michael F. Thies. 2001. "The Causes of Electoral Reform in Japan.” In Mixed-Member Electoral Systems: The Best of Both Worlds?, eds. Matthew Soberg Shugart and Martin P. Wattenberg, 152-72. Oxford: Oxford University Press.

Rodden, Jonathan. 2009. "Back to the Future: Endogenous Institutions and Comparative Politics.” In Comparative Politics: Rationality, Culture, and Structure, eds. Mark Lichback and Alan Zuckerman, 333-57. 2nd ed. Cambridge: Cambridge University Press.

Saito, Jun. 2009. "Pork Barrel Politics and Partisan Realignment in Japan.” In Political Change in Japan: Electoral Behavior, Party Realignment, and the Koizumi Reforms, eds. Kenneth Mori McElwain, Steven R. Reed, and Kay Shimizu, 6786. Stanford, Calif.: Walter H. Shorenstein Asia-Pacific Research Center.

Scheiner, Ethan. 2006. Democracy Without Competition in Japan: Opposition Failure in a One-Party Dominant State. Cambridge: Cambridge University Press.

Selway, Joel Sawat. 2011. "Electoral Reform and Public Policy Outcomes in Thailand: The Politics of the 30-Baht Health Scheme." World Politics 63(1):165-202.

Shugart, Matthew Soberg, and Martin P. Wattenberg. 2001. Mixed-Member Electoral Systems: The Best of Both Worlds? Oxford: Oxford University Press.

Thabchumpon, Naruemon. 2002. "NGOs and Grassroots Participation in the Political Reform Process.” In Reforming Thai Politics, ed. Duncan McCargo, 183-201. Copenhagen: Nordic Institute of Asian Studies. 


\section{0}

Ray Christensen and Joel Sawat Selway

Thailand Budget Bureau. 2005-12. Thailand's Budget in Brief: Fiscal Years 2005-2012. Bangkok: Office of the Prime Minister, Royal Thai Government.

Thames, Frank C., and Martin S. Edwards. 2006. "Differentiating Mixed-Member Electoral Systems: Mixed-Member Majoritarian and Mixed-Member Proportional Systems and Government Expenditures." Comparative Political Studies 39(7): 905-27.

Ticchi, Davide, and Andrea Vindigni. 2010. "Endogenous Constitutions." Economic Journal 120(543):1-39.

Wasi, Prawase. 2002. “An Overview of Political Reform.” In Reforming Thai Politics, ed. Duncan McCargo, 21-28. Copenhagen: Nordic Institute of Asian Studies. 